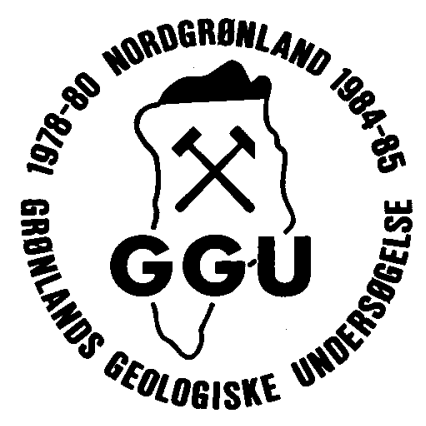

\title{
Late Silurian plant megafossils from the Peary Land Group, North Greenland
}

\author{
P.-H. Larsen, D. Edwards and J. C. \\ Escher
}

\begin{abstract}
Late Silurian plant megafossils including Hostinella and Salopella are described for the first time from Greenland. The plants are recovered from Ludlow strata within the deep-water turbidites of the Peary Land Group in central and western North Greenland. The remains are among the oldest known terrestrial plant megafossils. The plant assemblage is briefly compared with assemblages of Silurian age elsewhere and its palaeo- geographic significance is evaluated.

P.-H. L. \& J. C. E., Grønlands Geologiske Undersøgelse, $\emptyset$ ster Voldgade 10, DK-1350 Copenhagen K, Denmark.

D. E., Department of Plant Science, University College, Cardiff CF1 IXL, Wales, U. K.
\end{abstract}

During the 1985 expedition to central and western North Greenland, Late Silurian plants were recovered from turbidites of the Peary Land Group (Hurst \& Surlyk, 1982; Surlyk \& Hurst, 1984; Larsen \& Escher, 1985, 1987). This Late Silurian plant material is among the oldest known assemblages of terrestrial land plants and is the oldest occurrence of plant megafossils in Greenland.

In this preliminary report the fossil plants from the Peary Land Group are briefly described and their relationships with occurrences of early Palaeozoic plants elsewhere are discussed.

\section{Distribution, stratigraphy and age}

The plant assemblages were recovered from four different localities, viz. Nares Land, Wulff Land, Nyeboe Land, and Hall Land (fig. 1). In all instances the plant remains occur within strata referred to as the upper mapping unit of the Lauge Koch Land Formation by Larsen \& Escher (1985) and named the Nyeboe Land Formation by Larsen \& Escher (1987). The unit is widely distributed in western and central North Greenland and is dominated by fine sandstone turbidites interbedded with fine-grained siltstone and mudstone intervals. The fossil plants occur both in the sandstones and in the finer-grained lithologies (fig. 2).

The occurrence of the graptolites Bohemograptus bohemicus and Saetograptus fritschi linearis below the formation in Permin Land, and the occurrence of Pristiograptus dubius above the unit in north-eastern Nyeboe Land indicates a Ludlow age for the plant-bearing Nyeboe Land Formation. 


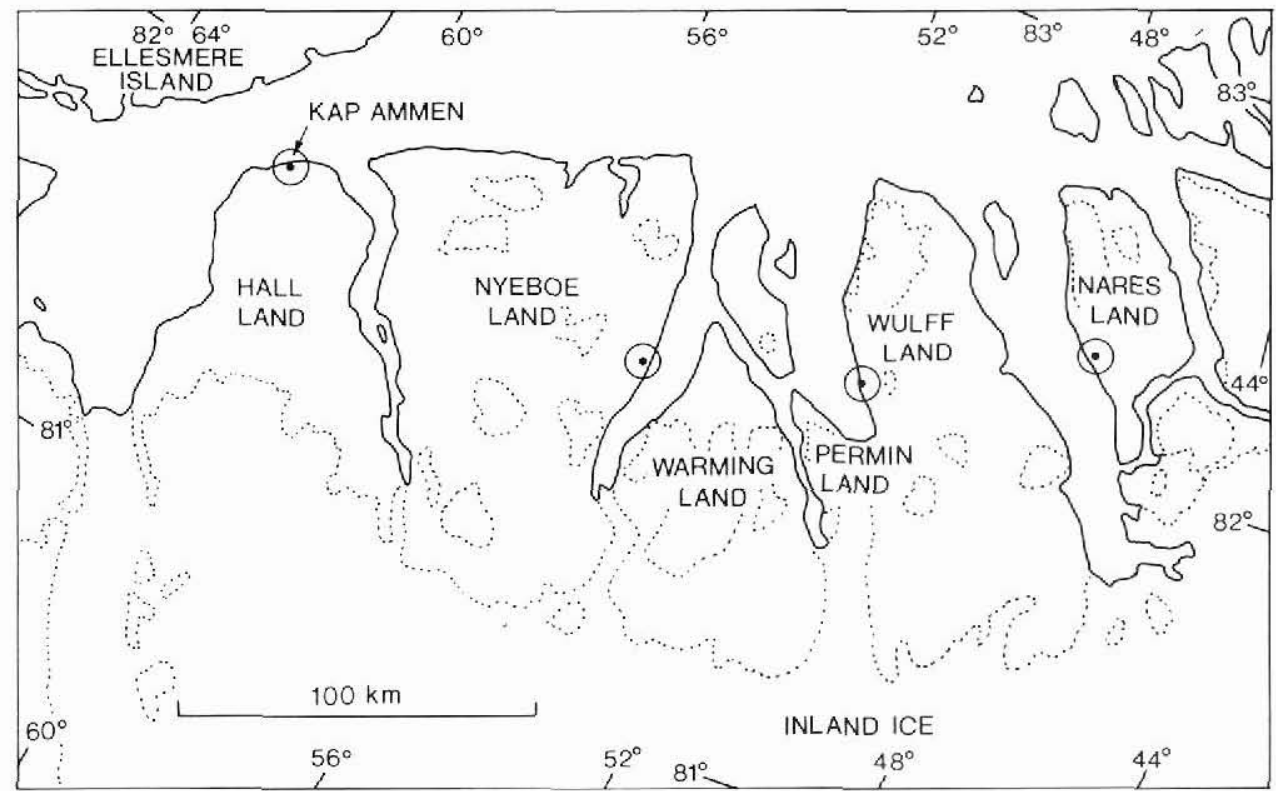

Fig. 1. Collection localities in central and western North Greenland for Late Silurian plant megafossils described in this paper.

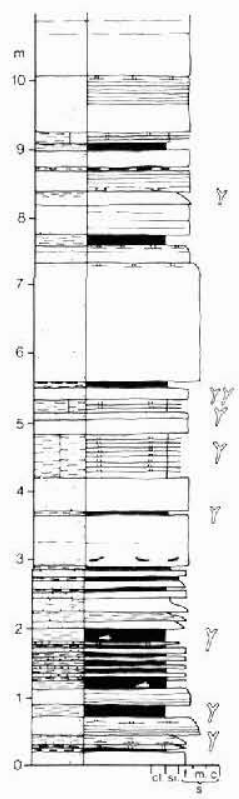

Fig. 2. Details of sediment log through a turbidite sequence of the Nyeboe Land Formation in Wulff Land. Occurrences of fossil plants are indicated. 
In Nares Land (fig. 1) more detailed information about the age of the fossil plants is available as Bohemograptus bohemicus was collected both below and above an occurrence of Hostinella, namely a few metres below and approximately $165 \mathrm{~m}$ above the plant remains. As the graptolite assemblages indicate a Ludlow age, the plants must also be Ludlow. The rarity of graptolite material at this locality, and the as yet not well defined Ludlow graptolite biostratigraphical zonation in North Greenland, make it difficult to place the finds of $H o s$ tinella more precisely within the Ludlow series. However, the occurrence of $B$. bohemicus both below and well above the fossil plant suggests that the remains in Nares Land come from the middle part of Ludlow. Detailed age information concerning the other plant localities is not yet available.

\section{Plant material}

The plant fossils are all fragmentary, the vast majority being preserved as coalified compressions. Initial investigations have failed to reveal any anatomical details; a very small number of fossils are pyritised and after preparation may be informative in this respect. The most fossiliferous strata are in Wulff Land (fig. 2). The specimens found here are the best preserved with fragments of axes, sometimes showing current alignment, exposed on bedding planes in fine grained, light grey siltstones (figs 3,4). Some bedding planes are covered with flattened, usually irregularly shaped patches of coalified material (fig. 5) with very occasional short lengths of usually unbranched axes. Such specimens look very similar to those described from Ludlow strata at Capel Horeb, South Wales (Edwards, 1982). Far less easy to study are fragments showing no preferred orientation and dispersed irregularly throughout a darker grey, coarser matrix, possibly a fine-grained sandstone with irregular fracture (fig. 6).

Although a few of the coalified fossils with axial organisation may belong to Prototaxites, a genus of uncertain but possible algal affinity, the majority are probably the sterile remains of higher plants. These are slender, smooth and parallel-sided and exhibit occasional isotomous branching. Forking specimens may be assigned to Hostinella (fig. 3), although direct evidence for their vascular nature is lacking. A few display a central dark line probably representing conducting tissues. The majority of these axes are about $1 \mathrm{~mm}$ or slightly less in diameter; a few attain $3 \mathrm{~mm}$, and such examples may be several centimetres long (fig. 7). They are therefore considerably larger than axes of comparable age elsewhere.

The discovery of fertile specimens in assemblages of drifted remains is either a result of chance or of exceedingly time-consuming preparation in the laboratory. In some cases the rock splits fortuitously revealing a cleaved sporangium, as illustrated in fig. 4; in others, grains of sediment must be removed from around or above apparent ends of axes in the hope of revealing sporangia. It has not yet been possible to prepare the Greenland specimens in this way. Fig. 4 shows a plant fragment comprising smooth axes, with two branch points and three terminal, fusiform sporangia. The specimen has a maximum length of $13 \mathrm{~mm}$ with an axis diameter of $0.83 \mathrm{~mm}$ at its base. The most complete sporangium has an acuminate tip and is about $3.4 \mathrm{~mm}$ long and $0.83 \mathrm{~mm}$ wide at its widest point; the junction between sporangium and subtending axis is not distinct. Sporangia of this shape, which occur at the termination of smooth isotomously branching axes, belong to the form genus Salopella, originally based on early Devonian specimens from the Welsh Borderland (Edwards \& Richardson, 1974). The Greenland example is much smaller than the type species $S$. allenii and is closer to specimens currently being investigated from Pridoli (Late Silurian) and early Gedinnian strata in the Welsh Borderland (see illustration in Edwards \& Fanning, 1985, Plate 1, figs 9, 10; Richardson \& Edwards, in press). 

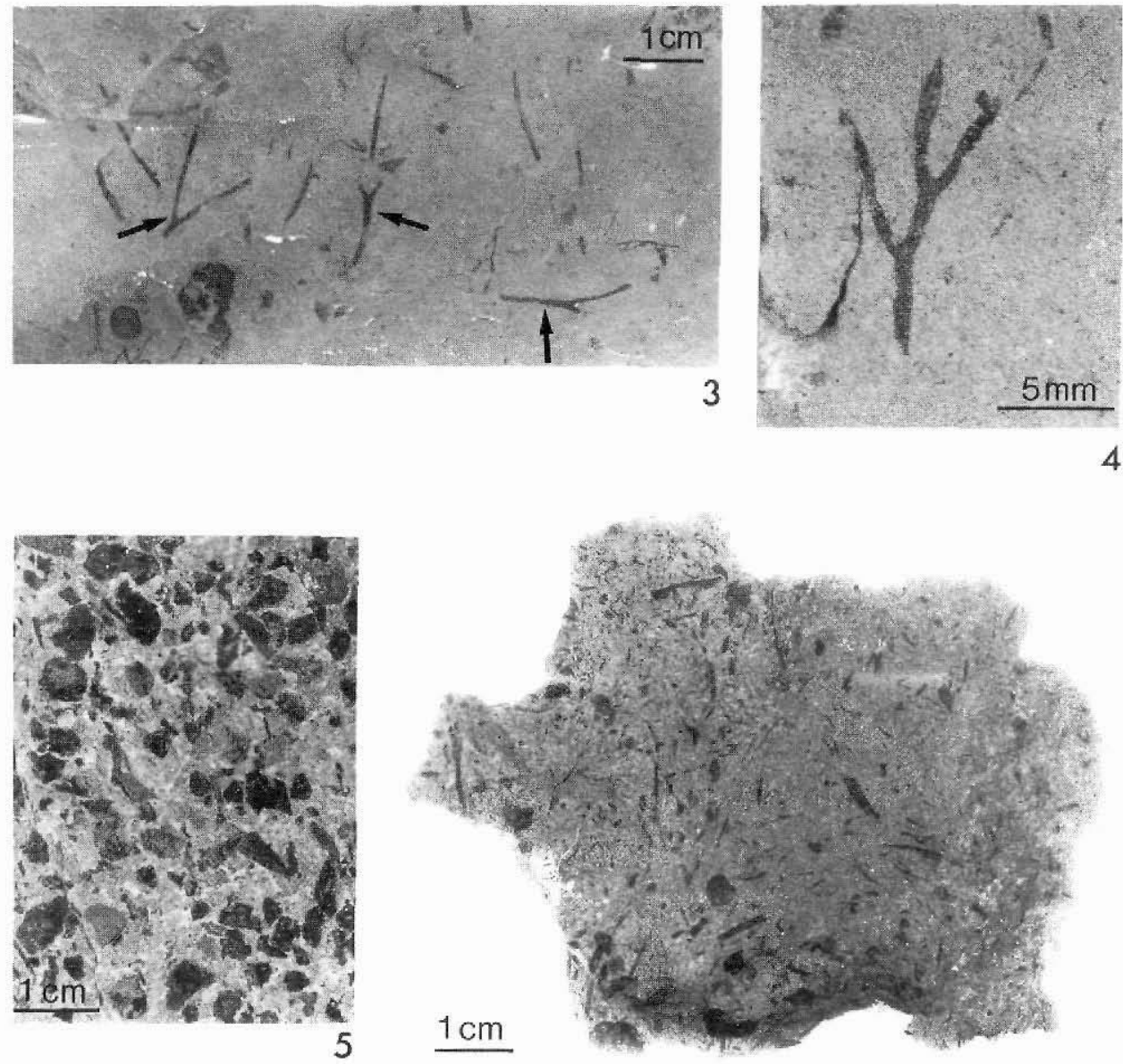

6

Fig. 3. Plant fragments including Hostinella (arrows) numbered

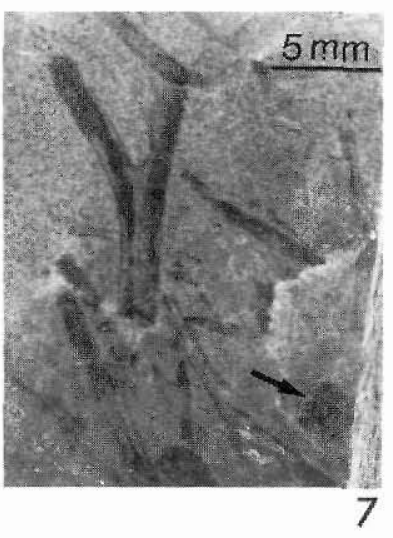
from left to right MGUH 17460-62 from GGU 319210. From Wulff Land.

Fig. 4. Salopella sp. MGUH 17464 from GGU 319207. From Wulff Land.

Fig. 5. Flattened irregularly shaped coalified fragments with occasional unbranched axis: GGU 319204. From Wulff Land.

Fig. 6. Diverse coalified remains including some axes irregularly distributed throughout the matrix: GGU 319234. From Nyeboe Land.

Fig. 7. An atypically large Hostinella, MGUH 17463 from GGU 319210 associated with coalified debris and a possible sporangium (arrow), MGUH 17465 from GGU 319210. From Wullf Land. 
The only other possible fertile specimen so far discovered (arrowed in fig. 7) is a rounded structure (c. $2.8 \mathrm{~mm}$ maximum diameter) with an encircling but incomplete border (c. 0.25 $\mathrm{mm}$ wide). This may represent an isolated terminal sporangium of Cooksonia caledonica type (Edwards, 1970) or an isolated sporangium lacking a stalk from a Zosterophyllum spike. The latter seems less likely as such sporangia are rarely isodiametric in face view (Edwards, 1975).

\section{Discussion}

The discovery of fossil plants in the Ludlow turbidites from central and western North Greenland is of importance for two reasons: Silurian occurrences of megafossils of presumed land plants are rare, and a preliminary examination suggests that the plants themselves are not exactly comparable with those in Ludlow assemblages elsewhere in the northern hemisphere.

Richardson \& Edwards (in press) list 15 Silurian localities at which land plants have been recorded. Most assemblages contain fertile specimens. Nine are from Pridoli strata, three from Ludlow, one from Wenlock, one from Llandovery strata and one is indeterminate, possibly Wenlock. The two northern hemisphere Ludlow localities are in Wales; the plants are exclusively rhyniophytes (Edwards \& Rogerson, 1979; Edwards et al., 1979) with Cooksonia (Gorstian and Ludfordian) and Steganotheca (Ludfordian) in addition to abundant smooth isotomously branching axes assigned to Hostinella. The third record is in Victoria, Australia, where the assemblage is far more diverse, containing Baragwanathia, often regarded as the earliest representative of the lycopods, and two rhyniophytes, Salopella and Hedeia (Tims \& Chambers, 1984). This disparity in composition between Australia and the present northern hemisphere has presented a major challenge to conventional ideas on the phylogeny of early vascular plants (see e.g. Gray \& Boucot, 1978; Boucot \& Gray, 1982; Edwards \& Fanning, 1985 ) and such a controversy will be resolved only by the discovery and description of new assemblages of both micro- and megafossils from exposures throughout the Silurian from as wide a geographical area as possible.

It is far too early to evaluate fully the contribution of the Greenland material to this debate. It certainly provides a new record some distance away from those already known and, at first glance, on the basis of the dimensions of the plant axes, the assemblage has more in common with Gedinnian assemblages elsewhere in the northern hemisphere. As to composition, however, all the axes show the characteristic isotomous branching of Hostinella; the overtopping seen in the early Devonian of Britain has not yet been observed (Lele \& Walton, 1961; Edwards \& Fanning, 1985). The most convincing fertile remains so far identified are assigned to Salopella, known also from the Ludlow of Australia and from the Pridoli and Gedinnian of southern Britain (Edwards \& Fanning, 1985; Richardson \& Edwards, in press). Preliminary examination has not indicated the presence of either Baragwanathia or Zosterophyllum, the latter characterising the early Devonian in Great Britain and Belgium (Leclercq, 1942).

Acknowledgements. We extend our thanks to Merete Bjerreskov (University of Copenhagen) for the determination of the graptolites and to Bodil Sikker Hansen and Birgitte Larsen for technical assistance. The prefix MGUH denotes the type collection of the Geological Museum, Copenhagen, Denmark. 


\section{References}

Boucot, A. J. \& Gray, J. 1982: Geologic correlates of early land plant evolution. Proc. Third North American Paleontol. Conv. 1, 61-66.

Edwards, D. 1970: Fertile Rhyniophytina from the Lower Devonian of Britain. Palaeontology 13, 451461.

Edwards, D. 1975: Some observations on the fertile parts of Zosterophyllum myretonianum Penhallow from the Lower Old Red Sandstone of Scotland. Trans. R. Soc. Edinb. 69, 251-265.

Edwards, D. 1982: Fragmentary non-vascular plant microfossils from the late Silurian of Wales. Bot. J. Linn. Soc. 84, 223-256.

Edwards, D. \& Fanning, U. 1985: Evolution and environment in the late Silurian - early Devonian: the rise of the pteridophytes. Phil. Trans. R. Soc. Lond. 309B, 147-165.

Edwards, D. \& Richardson, J. B. 1974: Lower Devonian (Dittonian) plants from the Welsh Borderland. Palaeontology 17, 311-324.

Edwards, D. \& Rogerson, E. C. W. 1979: New records of fertile Rhyniophytina from the late Silurian of Wales. Geol. Mag. 116, 93-95.

Edwards, D., Bassett, M. G. \& Rogerson, E. C. W. 1979: The earliest vascular land plants; continuing the search for proof. Lethaia 12, 313-324.

Gray, J. \& Boucot, A. J. 1978: The advent of land plant life. Geology 6, 489-492.

Hurst, J. M. \& Surlyk, F. 1982: Stratigraphy of the Silurian turbidite sequence of North Greenland. Bull. Grønlands geol. Unders. 145, 121 pp.

Larsen, P.-H. \& Escher, J. C. 1985: The Silurian turbidite sequence of the Peary Land Group between Newman Bugt and Victoria Fjord, western North Greenland. Rapp. Grønlands geol. Unders. 126, $47-67$.

Larsen, P.-H. \& Escher, J. C. 1987: Additions to the lithostratigraphy of the Peary Land Group (Silurian) in western and central North Greenland. Rapp. Grønlands geol. Unders. 133, 65-80.

Leclercq, S. 1942: Quelques plantes fossiles recueillies dans le Dévonien inférieur des environs de Nonceveux (Bordure orientale du bassin de Dinant). Annls Soc. géol. Belg. 65, 193-211.

Lele, K. M. \& Walton, J. 1961: Contributions to the knowledge of Zosterophyllum myretonianum Penhallow from the Lower Old Red Sandstone of Angus. Trans. R. Soc. Edinb. 64, 469-475.

Richardson, J. B. \& Edwards, D. (in press): Palynomorphs and plant megafossils. In Holland, C. H. \& Bassett, M. G. (edit.) A global standard for the Silurian System.

Surlyk, F. \& Hurst, J. M. 1984: The evolution of the early Paleozoic deep-water basin of North Greenland. Bull. geol. Soc. Am. 95, 131-154.

Tims, J. D. \& Chambers, J. C. 1984: Rhyniophytina and Trimerophytina from the early land floras of Victoria. Palaeontology 27, 265-279. 